\title{
The digestion by cattle of silage-containing diets fed at two dry matter intakes
}

\author{
*2. Digestion of total amino acids and of D-alanine \\ and D-glutamic acid
}

\author{
By H. A. GREIFE†, J. A. ROOKE $\ddagger$ AND D. G. ARMSTRONG \\ Department of Agricultural Biochemistry and Nutrition, \\ University of Newcastle upon Tyne, Newcastle upon Tyne, NE1 $7 R U$
}

(Received 27 June 1984 - Accepted 18 April 1985)

1. In a $4 \times 4$ Latin square experiment four cows were given, twice daily, diets consisting of ( $\mathrm{g} / \mathrm{kg}$ dry matter (DM) 500 barley, 400 grass silage and 100 soya-bean meal. The diets were given at either $1 \cdot 15(\mathrm{~L})$ or $2 \cdot 3(\mathrm{H})$ times maintenance energy requirements and the soya-bean meal was either untreated (U) or formaldehyde (HCHO)-treated (T).

2. The passage of digesta to the duodenum was estimated using chromic oxide as a flow marker; ${ }^{35} \mathrm{~S}$ was used to estimate the amount of microbial protein entering the small intestine. A microbial fraction was prepared by differential centrifugation from duodenal digesta. Samples of bacteria and of protozoa from rumen digesta were also prepared.

3. The total amino acid contents of feedingstuffs, duodenal digesta, duodenal microbial material, rumen bacteria and rumen protozoa were determined by ion-exchange chromatography. The D-alanine and D-glutamic acid contents of the samples were determined by gas-liquid chromatography.

4. The quantity of each amino acid entering the small intestine was significantly $(P<0.001)$ increased by increasing DM intake and tended to be increased by formaldehyde-treatment of the soya-bean meal. There were net losses of all amino acids across the forestomachs except for lysine, methione, D-alanine and D-glutamic acid for which there were net gains.

5. There were significant $(P<0 \cdot 05)$ differences in amino acid composition between rumen bacteria and duodenal microbial material; differences in amino acid composition between rumen bacteria and rumen protozoa were also observed.

6. D-Alanine and D-glutamic acid were present in the silage but not in the barley or either of the soya-bean meals. All samples of microbes and digesta contained D-alanine and D-glutamic acid.

7. The use of $\mathrm{D}$-alanine and $\mathrm{D}$-glutamic acid as markers for microbial nitrogen entering the small intestine was assessed. Estimates of the quantities of microbial $N$ entering the small intestine based on the D-alanine or D-glutamic acid contents of rumen bacteria or duodenal microbes were significantly higher than those determined using ${ }^{35} \mathrm{~S}$ as a marker.

The Agricultural Research Council (ARC) $(1980,1984)$ proposals for the protein rationing of ruminant livestock require the calculation of the amounts of microbial protein entering the small intestine. Total crude protein (nitrogen $\times 6 \cdot 25$ ) entering the small intestine is normally measured using animals equipped with abomasal or duodenal cannulas and the proportion of this protein which is microbial in origin is estimated from the relative concentrations of a marker substance in duodenal digesta and in a microbial fraction prepared from rumen or duodenal digesta. Methods for marking microbial protein include the isotopic labelling of protein by intraruminal infusion of ${ }^{15} \mathrm{NH}_{4}{ }^{+}$(Mathison \& Milligan, 1971) or ${ }^{35} \mathrm{SO}_{4}{ }^{2-}$ (Mathers \& Miller, 1980) and use of substances such as diaminopimelic acid (Hutton et al. 1970) or RNA (McAllan \& Smith, 1972) which are present as constitutive components in the microbes.

* Paper no. 1: British Journal of Nutrition (1985), 53, 691-708.

+ Present address: Institüt für Tierphysiologie und Tierernahrung der Universität Göttingen, Oskar-KellnerWeg 6, 3400 Göttingen-Weende, West Germany.

$\ddagger$ For reprints. 
Recently, Garrett et al. (1982) and McMillan (1982) have suggested that D-amino acids such as D-alanine and D-glutamic acid, which have the advantage over diaminopimelic acid of being present in both gram-positive and gram-negative bacterial cell walls (Schliefer \& Kandler, 1972), may also be used as markers for bacterial protein. With the objective of examining the use of D-amino acids as markers, the present paper reports the total amino acid, D-alanine and D-glutamic acid contents of feedingstuffs, duodenal digesta, duodenal microbial material, rumen bacteria and rumen protozoa determined in an experiment with cattle given silage and concentrate diets (Rooke et al. 1985). A preliminary account of some of the results has been published (Greife et al. 1983).

\section{EX PERIMENT A L}

\section{Animals, diet and experimental procedure}

Full details of the surgically-modified Jersey cattle used in the present experiment, of the diets and of the collection procedures are given by Rooke et al. (1985). Briefly, the experiment was designed as a $4 \times 4$ Latin square in which each of two diets was given at $1 \cdot 15(\mathrm{~L})$ or 2.3 (H) times maintenance energy requirements (Ministry of Agriculture, Fisheries and Food, 1975). The diets comprised (g dry matter (DM)/kg DM) 500 barley, 400 grass silage, 100 soya-bean meal, the last mentioned being given either as untreated (U) or as formaldehyde ( $\mathrm{HCHO}$ )-treated (T) meal.

In addition to the collections detailed by Rooke $e$ al. (1985), a bulk sample (approximately $1 \mathrm{~kg}$ ) of rumen digesta was obtained from each animal, by means of a vacuum pump, $1 \mathrm{~h}$ after the completion of each $24 \mathrm{~h}$ collection of duodenal digesta, i.e. at 09.00 hours on day 20. This sample of rumen digesta was used immediately to prepare samples of rumen bacteria and protozoa using the sedimentation and centrifugation procedures described by Czerkawski (1976) with the following modifications. First, rumen bacteria were not separated into large and small subfractions but prepared as one fraction by centrifugation at $20000 \mathrm{~g}$ for $30 \mathrm{~min}$. Second, during the repeated dilution and sedimentation procedure detailed by Czerkawski (1976) to collect protozoa from strained rumen contents, the material which sedimented at $37^{\circ}$ was not discarded but was combined and washed three times with saline ( $9 \mathrm{~g}$ sodium chloride $/ 1)$. This fraction, which was found to consist largely of protozoa, was called the protozoal sediment, in contrast to the protozoal fraction isolated by Czerkawski (1976); this last-mentioned fraction is referred to as the protozoal supernatant fraction. The samples of rumen bacteria and protozoa were freeze-dried and stored at $-20^{\circ}$ before analysis.

\section{Analytical procedures}

In addition to the analytical procedures detailed by Rooke et al. (1985), the concentrations of D-alanine and D-glutamic acid in milled feedingstuffs, and freeze-dried and milled duodenal digesta, duodenal microbial fraction and rumen bacteria and protozoa were determined as follows. Total amino acid contents of the samples were determined by automated ion-exchange chromatography of $6 \mathrm{M}$-hydrochloric acid hydrolysates and the D-alanine and D-glutamic acid contents of the hydrolysates determined according to McMillan (1982). After the acid hydrolysates were purified by cation-exchange chromatography (Kaiser et al. 1974), the amino acids were converted to their $\mathrm{N}$ (O, S)pentafluoropropionyl D,L-amino acid isopropyl esters according to the procedures used by Frank et al. (1978). The D and $\mathrm{L}$ amino acid derivatives so prepared were then separated by capillary gas-liquid chromatography (McMillan, 1982), using a $25 \mathrm{~m}$ Chirasil-Val glass capillary column (Pierce \& Warriner, UK Ltd, Chester). 
Tabie 1. The concentrations ( $\mathrm{g} / \mathrm{kg}$ dry matter) of total nitrogen, amino acid- $N$, individual amino acids and D-alanine and D-glutamic acid in the feeds

\begin{tabular}{|c|c|c|c|c|}
\hline & \multirow[b]{2}{*}{ Silage* } & \multirow[b]{2}{*}{ Barley } & \multicolumn{2}{|c|}{ Soya-bean meal } \\
\hline & & & Untreated & HCHO-treated \\
\hline Arginine & $3 \cdot 2$ & $5 \cdot 5$ & $39 \cdot 1$ & $42 \cdot 6$ \\
\hline Histidine & $2 \cdot 7$ & $2 \cdot 6$ & $16 \cdot 5$ & 14.7 \\
\hline Isoleucine & $6 \cdot 1$ & $4 \cdot 0$ & $25 \cdot 6$ & $26 \cdot 0$ \\
\hline Leucine & 8.9 & $7 \cdot 4$ & $42 \cdot 9$ & $45 \cdot 1$ \\
\hline Lysine & $5 \cdot 5$ & $4 \cdot 1$ & $35 \cdot 6$ & $31 \cdot 1$ \\
\hline Methionine & 1.0 & $1 \cdot 4$ & $6 \cdot 2$ & $6 \cdot 2$ \\
\hline Phenylalanine & 5.6 & $4 \cdot 8$ & $27 \cdot 4$ & $27 \cdot 2$ \\
\hline Threonine & $6 \cdot 5$ & $4 \cdot 3$ & $24 \cdot 9$ & $25 \cdot 3$ \\
\hline Valine & $8 \cdot 3$ & $5 \cdot 7$ & $26 \cdot 3$ & $26 \cdot 1$ \\
\hline Alanine & $9 \cdot 8$ & $4 \cdot 5$ & $26 \cdot 0$ & $25 \cdot 0$ \\
\hline D-Alanine & 0.6 & 0.0 & 0.0 & $0 \cdot 0$ \\
\hline Aspartic acid & $14 \cdot 4$ & $7 \cdot 2$ & $67 \cdot 1$ & 67.8 \\
\hline Glutamic acid & $14 \cdot 1$ & $25 \cdot 5$ & $112 \cdot 3$ & $114 \cdot 0$ \\
\hline D-Glutamic acid & 0.5 & $0 \cdot 0$ & 0.0 & $0 \cdot 0$ \\
\hline Glycine & $6 \cdot 2$ & $4 \cdot 8$ & $23 \cdot 6$ & $24 \cdot 7$ \\
\hline Proline & $9 \cdot 9$ & $12 \cdot 1$ & 30.9 & $31 \cdot 4$ \\
\hline Serine & $6 \cdot 3$ & $5 \cdot 4$ & 31.9 & $32 \cdot 7$ \\
\hline Tyrosine & $2 \cdot 8$ & 3.0 & $20 \cdot 7$ & $17 \cdot 1$ \\
\hline Amino acid $\mathrm{N}$ & $15 \cdot 1$ & 13.5 & $76 \cdot 0$ & $76 \cdot 3$ \\
\hline Total N & $20 \cdot 8$ & $15 \cdot 7$ & $83 \cdot 7$ & $84 \cdot 0$ \\
\hline
\end{tabular}

* Dry matter determined by toluene distillation.

Calculations and statistical analysis

The quantities of DM entering the small intestines of the cattle daily were corrected for complete recovery of chromic oxide. The concentrations of D-alanine and D-glutamic acid in the samples, as determined by gas-liquid chromatography, were corrected for the racemization which occurred during acid hydrolysis using the following equations (McMillan, 1982):

$$
\mathrm{L} 1=\frac{(\mathrm{L} 1+\mathrm{D} 1)}{1+(((1-x) \mathrm{D} 2-x \mathrm{~L} 2) /((1-x) \mathrm{L} 2-x \mathrm{D} 2))},
$$

and

$$
\mathrm{D} 1=(\mathrm{L} 1+\mathrm{D} 1)-\mathrm{L} 1,
$$

where $(L 1+D 1)$ is the total $(D+L)$ concentration $(g / k g D M)$ of the amino acid in the sample determined by ion-exchange chromatography; $L 1$ and $D 1$ are the concentrations ( $/ \mathrm{kg} D M$ ) of the $\mathrm{L}$ and $\mathrm{D}$ isomers of the amino acid originally present in the sample; $\mathrm{L} 2$ and $\mathrm{D} 2$ are the concentrations $(\mathrm{g} / \mathrm{kg} \mathrm{DM}$ ) of the $\mathrm{L}$ and $\mathrm{D}$ isomers of the amino acid determined by gas-liquid chromatography and $x$ is the proportional racemization correction factor. As previously discussed (Rooke et al. 1984), the extent to which pure proteins undergo racemization during acid hydrolysis overestimates the extent to which feed proteins undergo racemization. Therefore, proportional racemization correction factors of 0.0187 for D-alanine and 0.0257 for D-glutamic acid were determined from measurements of the extent to which the barley and the soya-bean meals used in this experiment underwent racemization during acid hydrolysis.

Analysis of variance techniques for Latin-square design experiments were used where applicable. Paired $t$ tests were used to assess differences in composition between the different fractions obtained from the digestive tract. 
Table 2. The mean quantities of dry matter, total nitrogen, amino acid- $N$, individual amino acids and D-alanine and D-glutamic acid entering the small intestines of cattle given each of the four diets

(The values are expressed as $\mathrm{g} / 24 \mathrm{~h}$ and $\mathrm{g} / \mathrm{g}$ ingested)

\begin{tabular}{|c|c|c|c|c|c|c|c|}
\hline & \multicolumn{4}{|c|}{ Diet ${ }^{\dagger}$} & \multirow[b]{2}{*}{ SE } & \multicolumn{2}{|c|}{$\begin{array}{l}\text { Statistical } \\
\text { significance } \\
\text { of effects }\end{array}$} \\
\hline & $\mathrm{LU}$ & $\mathbf{L T}$ & $\mathrm{HU}$ & $\mathrm{HT}$ & & $\mathbf{L} v \cdot \mathbf{H}$ & $\mathrm{U} v . \mathrm{T}$ \\
\hline \multicolumn{8}{|l|}{ Arginine } \\
\hline $\mathrm{g} / 24 \mathrm{~h}$ & $20 \cdot 3$ & $25 \cdot 1$ & $42 \cdot 6$ & $54 \cdot 2$ & 3.68 & $* * *$ & NS \\
\hline $\mathrm{g} / \mathrm{g}$ & 0.79 & 0.93 & 0.88 & $1 \cdot 08$ & 0.08 & & \\
\hline \multicolumn{8}{|l|}{ Histidine } \\
\hline $\mathrm{g} / 24 \mathrm{~h}$ & $9 \cdot 0$ & $9 \cdot 9$ & $17 \cdot 7$ & $21 \cdot 3$ & $1 \cdot 20$ & $* * *$ & NS \\
\hline $\mathrm{g} / \mathrm{g}$ & 0.69 & 0.79 & 0.72 & 0.91 & 0.07 & & \\
\hline \multicolumn{8}{|l|}{ Isoleucine } \\
\hline $\mathrm{g} / 24 \mathrm{~h}$ & $20 \cdot 5$ & $22 \cdot 4$ & $44 \cdot 1$ & $45 \cdot 5$ & $2 \cdot 87$ & $* * *$ & NS \\
\hline $\mathrm{g} / \mathrm{g}$ & 0.89 & 0.97 & 1.02 & 1.06 & 0.08 & & \\
\hline \multicolumn{8}{|l|}{ Leucine } \\
\hline $\mathrm{g} / 24 \mathrm{~h}$ & 27.0 & $31 \cdot 1$ & $58 \cdot 3$ & $63 \cdot 8$ & 3.56 & $* * *$ & NS \\
\hline $\mathrm{g} / \mathrm{g}$ & 0.72 & 0.81 & 0.82 & 0.89 & 0.06 & & \\
\hline \multicolumn{8}{|l|}{ Lysine } \\
\hline $\mathrm{g} / 24 \mathrm{~h}$ & $25 \cdot 8$ & $30 \cdot 3$ & $55 \cdot 8$ & $62 \cdot 5$ & $3 \cdot 35$ & $* * *$ & NS \\
\hline $\mathrm{g} / \mathrm{g}$ & $1 \cdot 01$ & $1 \cdot 25$ & $1 \cdot 17$ & $1 \cdot 39$ & 0.09 & & \\
\hline \multicolumn{8}{|c|}{ Methionine } \\
\hline $\mathrm{g} / 24 \mathrm{~h}$ & $5 \cdot 7$ & 6.0 & $14 \cdot 1$ & $15 \cdot 1$ & $1 \cdot 34$ & $* * *$ & NS \\
\hline $\mathrm{g} / \mathrm{g}$ & $1 \cdot 01$ & 1.09 & $1 \cdot 35$ & 1.45 & 0.15 & & \\
\hline \multicolumn{8}{|c|}{ Phenylalanine } \\
\hline $\mathrm{g} / 24 \mathrm{~h}$ & 16.5 & $19 \cdot 1$ & $36 \cdot 1$ & $39 \cdot 8$ & $2 \cdot 08$ & $* * *$ & NS \\
\hline $\mathrm{g} / \mathrm{g}$ & 0.68 & 0.79 & $0 \cdot 80$ & 0.88 & 0.06 & & \\
\hline \multicolumn{8}{|l|}{ Threonine } \\
\hline $\mathrm{g} / 24 \mathrm{~h}$ & $21 \cdot 0$ & $22 \cdot 9$ & $45 \cdot 1$ & $47 \cdot 6$ & $2 \cdot 50$ & $* * *$ & NS \\
\hline $\mathrm{g} / \mathrm{g}$ & 0.89 & 0.96 & $1 \cdot 01$ & 1.07 & 0.07 & & \\
\hline \multicolumn{8}{|l|}{ Valine } \\
\hline $\mathrm{g} / 24 \mathrm{~h}$ & $20 \cdot 0$ & $22 \cdot 9$ & $44 \cdot 0$ & $46 \cdot 6$ & 2.55 & $* * *$ & NS \\
\hline $\mathrm{g} / \mathrm{g}$ & 0.69 & 0.79 & 0.81 & 0.87 & 0.06 & & \\
\hline \multicolumn{8}{|l|}{ Alanine } \\
\hline $\mathrm{g} / 24 \mathrm{~h}$ & $24 \cdot 4$ & 26.4 & $52 \cdot 6$ & $56 \cdot 1$ & $3 \cdot 10$ & $* * *$ & NS \\
\hline $\mathrm{g} / \mathrm{g}$ & 0.83 & 0.90 & 0.95 & 1.03 & 0.08 & & \\
\hline \multicolumn{8}{|l|}{ D-Alanine } \\
\hline $\mathrm{g} / 24 \mathrm{~h}$ & $1 \cdot 1$ & $1 \cdot 1$ & $2 \cdot 6$ & $2 \cdot 5$ & $0 \cdot 18$ & $* * *$ & NS \\
\hline $\mathrm{g} / \mathrm{g}$ & $1 \cdot 23$ & $1 \cdot 22$ & $1 \cdot 51$ & 1.53 & $0 \cdot 14$ & & \\
\hline \multicolumn{8}{|c|}{ Aspartic acid } \\
\hline $\mathrm{g} / 24 \mathrm{~h}$ & $41 \cdot 0$ & $48 \cdot 2$ & $89 \cdot 7$ & $100 \cdot 5$ & $5 \cdot 85$ & $* * *$ & NS \\
\hline $\mathrm{g} / \mathrm{g}$ & 0.78 & 0.91 & 0.91 & 1.02 & 0.08 & & \\
\hline \multicolumn{8}{|c|}{ Glutamic acid } \\
\hline $\mathrm{g} / 24 \mathrm{~h}$ & $50 \cdot 4$ & $61 \cdot 5$ & $112 \cdot 7$ & $131 \cdot 1$ & $8 \cdot 38$ & $* * *$ & NS \\
\hline $\mathrm{g} / \mathrm{g}$ & 0.53 & 0.64 & 0.62 & $0 \cdot 72$ & 0.06 & & \\
\hline \multicolumn{8}{|c|}{ D-Glutamic acid } \\
\hline $\mathrm{g} / 24 \mathrm{~h}$ & $2 \cdot 6$ & $2 \cdot 5$ & $5 \cdot 2$ & $5 \cdot 7$ & 0.50 & $* * *$ & NS \\
\hline $\mathrm{g} / \mathrm{g}$ & $3 \cdot 74$ & $3 \cdot 57$ & 4.04 & $4 \cdot 62$ & 0.50 & & \\
\hline \multicolumn{8}{|l|}{ Glycine } \\
\hline $\mathrm{g} / 24 \mathrm{~h}$ & $19 \cdot 2$ & $20 \cdot 7$ & $40 \cdot 2$ & $42 \cdot 7$ & $2 \cdot 44$ & $* * *$ & NS \\
\hline $\mathrm{g} / \mathrm{g}$ & 0.81 & $0 \cdot 86$ & 0.91 & 0.95 & 0.07 & & \\
\hline \multicolumn{8}{|l|}{ Proline } \\
\hline $\mathrm{g} / 24 \mathrm{~h}$ & $14 \cdot 5$ & $18 \cdot 8$ & $33 \cdot 8$ & $39 \cdot 3$ & $2 \cdot 30$ & $* * *$ & NS \\
\hline $\mathrm{g} / \mathrm{g}$ & 0.34 & $0 \cdot 44$ & 0.42 & 0.49 & 0.03 & & \\
\hline
\end{tabular}


Table 2. (cont.)

\begin{tabular}{|c|c|c|c|c|c|c|c|}
\hline & \multicolumn{4}{|c|}{ Diet $\dagger$} & \multirow[b]{2}{*}{$\mathbf{S E}$} & \multicolumn{2}{|c|}{$\begin{array}{c}\text { Statistical } \\
\text { significance } \\
\text { of effects }\end{array}$} \\
\hline & LU & LT & HU & HT & & $\mathbf{L} v \cdot \mathbf{H}$ & Uv.T \\
\hline \multicolumn{8}{|l|}{ Serine } \\
\hline $\mathrm{g} / 24 \mathrm{~h}$ & 19.8 & 22.5 & 40.9 & 45.8 & $2 \cdot 15$ & $* * *$ & NS \\
\hline $\mathrm{g} / \mathrm{g}$ & 0.72 & 0.81 & 0.79 & 0.88 & 0.06 & & \\
\hline \multicolumn{8}{|l|}{ Tyrosine } \\
\hline$g / 24 h$ & $15 \cdot 0$ & 16.8 & $32 \cdot 6$ & 33.9 & 1.91 & $* * *$ & NS \\
\hline $\mathrm{g} / \mathrm{g}$ & 0.98 & $1 \cdot 19$ & $1 \cdot 14$ & 1.28 & 0.08 & & \\
\hline \multicolumn{8}{|c|}{ Amino acid $\mathbf{N}$} \\
\hline$g / 24 h$ & $47 \cdot 8$ & $55 \cdot 5$ & $103 \cdot 1$ & $116 \cdot 2$ & $6 \cdot 40$ & $* * *$ & NS \\
\hline $\mathrm{g} / \mathrm{g}$ & 0.72 & 0.83 & 0.82 & 0.93 & 0.06 & & \\
\hline \multicolumn{8}{|l|}{ Total N } \\
\hline $\mathrm{g} / 24 \mathrm{~h}$ & $60 \cdot 6$ & $69 \cdot 6$ & $136 \cdot 0$ & 149.8 & $9 \cdot 19$ & $* * *$ & NS \\
\hline $\mathrm{g} / \mathrm{g}$ & 0.76 & 0.87 & 0.90 & 0.99 & 0.07 & & \\
\hline \multicolumn{8}{|c|}{ Dry matter } \\
\hline $\mathrm{g} / 24 \mathrm{~h}$ & $1 \cdot 47$ & $1 \cdot 50$ & $3 \cdot 00$ & $3 \cdot 16$ & 0.112 & $* * *$ & NS \\
\hline
\end{tabular}

L, low $(1 \cdot 15 \times$ maintenance energy $) ; \mathrm{H}$, high $(2 \cdot 3 \times$ maintenance energy $) ; \mathrm{U}$, untreated soya-bean meal; NS, not significant.

$* * * \quad P<0.001$.

$\dagger$ For details, see p. 483 and Table 1.

\section{RESULTS}

Table 1 shows the amino acid composition of the feedingstuffs. Only in the silage were any measurable quantities of D-alanine and D-glutamic acid present. HCHO-treatment of the soya-bean meal reduced the quantities of lysine and tyrosine present.

The mean quantities of each amino acid entering the small intestines of the cattle daily are shown in Table 2. Increasing the quantities of feed ingested significantly $(P<0.001)$ increased the quantities of each amino acid entering the small intestine daily. For each amino acid there were increases in the quantities entering the small intestine as a result of HCHO-treatment of the soya-bean meal; however, none of these increases reached statistical significance. Excepting lysine, methionine, D-alanine and D-glutamic acid, for which net gains were observed, there were net losses of each amino acid between the mouth and the proximal duodenum (Table 2). The net losses of glutamic acid and proline were especially marked. Increasing DM intake and also HCHO-treatment of the soya-bean meal reduced the size of the net losses of amino acids between the mouth and proximal duodenum.

Despite the increased quantities of each amino acid which entered the small intestine daily when HCHO-treated soya-bean meal was given, it can be calculated from Table 2 that the concentrations of each amino acid in duodenal digesta DM for the four diets were very similar. However, feeding the HCHO-treated soya-bean meal significantly $(P<0.05)$ increased the concentrations of arginine, lysine and proline in duodenal digesta DM.

The amino acid compositions of the microbial fractions isolated from duodenal digesta and rumen digesta are given in Table 3 . The values presented are the means of all sixteen samples obtained over the entire experiment as no significant $(P>0.05)$ differences were observed between diets. The amino acid composition of the rumen bacteria and protozoa 
$\frac{3}{3} \frac{3}{5}$

马

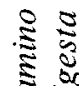

$\checkmark$

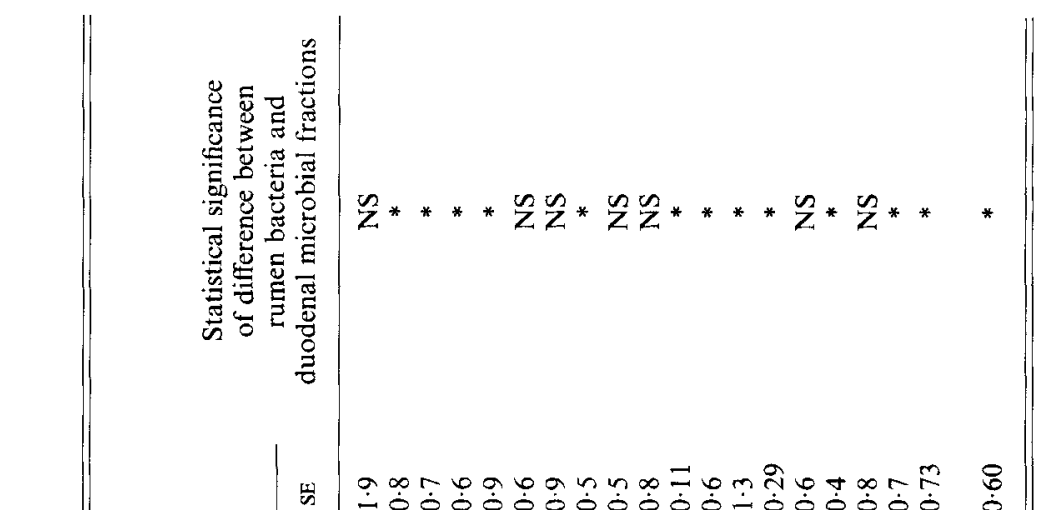

赵

कo

章

竞

응

氮

25

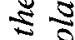

.

5

之.

ป

8

․․

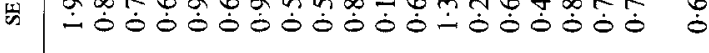

उี

ฐ

i

ฐ

ฐ

3 క

จ

so 0

$\frac{1}{60} \frac{1}{b}$

⿶o

ธี

$\stackrel{3}{3}$

5

क्ष

2.

₹

$m$

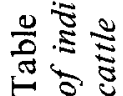

莺

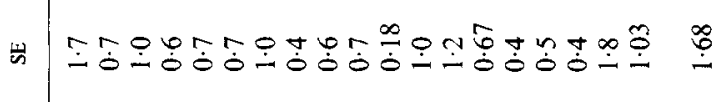

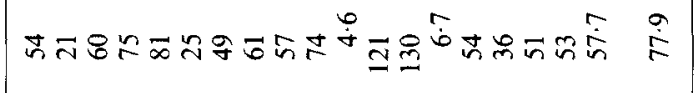

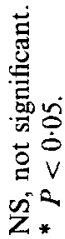




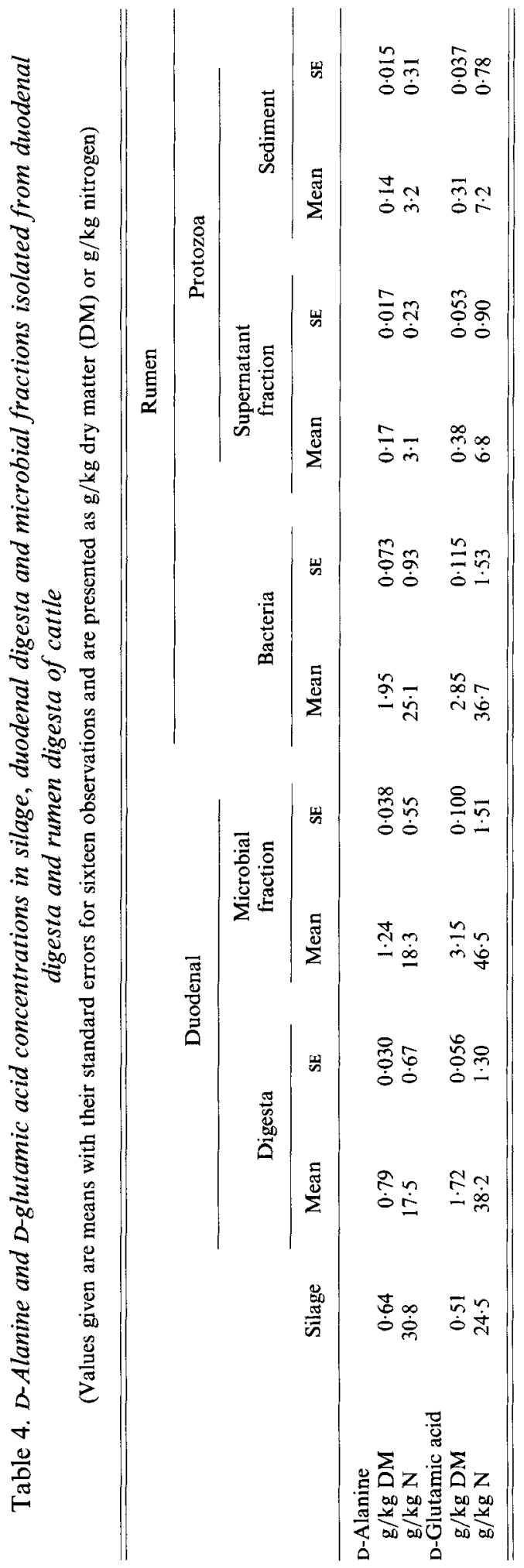


Table 5. The quantities of non-ammonia-nitrogen and of microbial $N(g / 24 h)$ entering the small intestines of cattle given each of four diets

(Microbial $\mathrm{N}$ was calculated using either ${ }^{35} \mathrm{~S}$ or the contents of D-alanine or D-glutamic acid in duodenal microbial material or rumen bacteria as markers for microbial $\mathrm{N}$. The values for the quantities of nonammonia- $\mathrm{N}$ and microbial $\mathrm{N}$, calculated using ${ }^{35} \mathrm{~S}$ as a marker, are taken from Rooke et al. 1985)

\begin{tabular}{|c|c|c|c|c|c|c|c|}
\hline & \multicolumn{4}{|c|}{ Diet $\dagger$} & \multirow[b]{2}{*}{ SE } & \multicolumn{2}{|c|}{$\begin{array}{l}\text { Statistical } \\
\text { significance } \\
\text { of effects }\end{array}$} \\
\hline & LU & LT & $\mathrm{HU}$ & HT & & Lv. $H$ & $U v . \mathrm{T}$ \\
\hline Non-ammonia $\mathbf{N}$ & $60 \cdot 6$ & $69 \cdot 6$ & $136 \cdot 0$ & $149 \cdot 8$ & $9 \cdot 19$ & $* * *$ & NS \\
\hline \multicolumn{8}{|l|}{ Microbial N: } \\
\hline Calculated from ${ }^{35} \mathrm{~S}$ & $45 \cdot 0$ & $46 \cdot 8$ & $97 \cdot 3$ & $89 \cdot 8$ & 4.92 & *** & NS \\
\hline \multicolumn{8}{|c|}{ Calculated from $\mathrm{D}$-amino acids in duodenal microbes: } \\
\hline D-Alanine & $58 \cdot 1$ & $62 \cdot 2$ & $139 \cdot 1$ & $143 \cdot 8$ & $8 \cdot 83$ & $* * *$ & NS \\
\hline D-Glutamic acid & $50 \cdot 4$ & $57 \cdot 4$ & $115 \cdot 7$ & $124 \cdot 9$ & $10 \cdot 33$ & *** & NS \\
\hline \multicolumn{8}{|c|}{ Calculated from $D$-amino acids in rumen bacteria: } \\
\hline D-Alanine & $44 \cdot 1$ & $45 \cdot 5$ & $106 \cdot 1$ & $97 \cdot 2$ & $7 \cdot 67$ & $* * *$ & NS \\
\hline D-Glutamic acid & $68 \cdot 3$ & $64 \cdot 9$ & $160 \cdot 8$ & $155 \cdot 4$ & $17 \cdot 33$ & *** & NS \\
\hline
\end{tabular}

$\mathrm{L}$, low ( $1.15 \times$ maintenance energy requirements $) ; \mathrm{H}$, high $(2.3 \times$ maintenance energy requirements); $U$, untreated soya-bean meal; $T$, formaldehyde-treated soya-bean meal; NS, not significant.

*** $P<0.001$.

$\uparrow$ For details, see p. 484 and Table 1.

were similar to those reported by Czerkawski (1976), Buttery (1982) and Storm \& Ørskov (1983). There were no differences in amino acid composition between the two protozoal fractions. However, the protozoal fraction which sedimented during incubation at $37^{\circ}$ contained significantly $(P<0.05)$ less total $\mathrm{N}$ and amino acid-N than that which remained in the supernatant fraction after incubation. Presumably the sedimenting protozoal fraction contained larger amounts of the protozoal storage carbohydrate (Williams \& Harfoot, 1976). The protozoal fractions had proportionately larger amounts of amino acid-N in total $\mathrm{N}$ than did the rumen bacteria, probably reflecting the lower proportions of nucleic acid- $\mathrm{N}$ in protozoal-N than in bacterial N (see Lindsay \& Armstrong, 1982).

When the amino acid compositions of the rumen bacterial and duodenal microbial isolates were compared, several significant differences were observed (Table 3 ). The most noticeable for the essential amino acids were for leucine, lysine and threonine and for the non-essential amino acids were for aspartic acid, glutamic acid, proline and tyrosine. In addition, as compared with the duodenal microbial fraction, the rumen bacteria contained significantly greater concentrations $(\mathrm{g} / \mathrm{kg} \mathrm{DM}$ ) of both total and amino acid-N.

The results relating to D-alanine and D-glutamic acid are summarized in Table 4 . There were differences between samples in D-alanine and $\mathrm{D}$-glutamic acid concentrations. It is noteworthy that for silage, the D-alanine:D-glutamic acid $(1 \cdot 25: 1)$ value was greater than for any of the fractions isolated from the digestive tract $(0 \cdot 39-0 \cdot 68: 1)$. Rumen bacteria contained significantly greater amounts of D-alanine than did the duodenal microbial fraction, which in turn contained greater amounts of the amino acid than did the rumen protozoa. Concentrations of D-glutamic acid were higher in the duodenal microbes than in the rumen bacteria which in turn had higher concentrations of the amino acid than did the rumen protozoa. The concentration of $\mathrm{D}$-alanine in duodenal digesta $(\mathrm{g} / \mathrm{kg} \mathrm{N})$ was 
similar to that found in duodenal microbes but significantly less than that found in rumen bacteria. However, the concentration of D-glutamic acid found in duodenal digesta $(\mathrm{g} / \mathrm{kg}$ $\mathrm{N})$ was similar to that found in rumen bacteria but significantly less than that found in the duodenal microbes.

\section{DISCUSSION}

D-Amino acids

As might be expected, D-alanine and D-glutamic acid were detected in silage but not in barley or either of the two soya-bean meals fed to the cattle; they were present in all samples obtained from rumen or duodenal digesta.

Rumen protozoa contained both D-alanine and D-glutamic acid but at only $0 \cdot 13$ and $0 \cdot 19$ times the concentration $(\mathrm{g} / \mathrm{kg}$ total $\mathrm{N})$ at which the acids were found in rumen bacteria. These values are similar to the corresponding value reported for diaminopimelic acid in rumen protozoa by Czerkawski (1976), who used the same isolation techniques as in the present study. Whether the D-alanine and D-glutamic acid in protozoa result from the engulfment of bacteria by protozoa (Coleman, 1975) or from the association of bacteria with protozoa (Vogels et al. 1980) is not clear. However, in view of the relatively low concentrations of the D-alanine and D-glutamic acid in protozoa and the selective retention of protozoa within the rumen (e.g. Harrison et al. 1979; Leng, 1982), the contribution of protozoal D-alanine and D-glutamic acid to the total amount of these acids entering the small intestine seems likely to be of little quantitative importance. Hence D-alanine and D-glutamic acid entering the small intestine can reasonably be regarded as markers of bacterial protein.

There were small but significant differences between rumen bacteria and the microbial fraction isolated from duodenal digesta in amino acid composition. Similar results have been reported by Siddons et al. (1982) for sheep given grass silage diets. The differences in amino acid composition cannot be explained at present. They were not, as might have been expected, consistent with the appearance of protozoal amino acids in the duodenal microbial material nor were they consistent with the observed losses of cytoplasmic material from bacteria as a result of proteolytic digestion in the abomasum (Mathers \& Miller, 1980). Had losses of cytoplasmic material occurred, then losses of free amino acids, especially of glutamic acid, which accounts for more than half the free amino acid pool of bacteria (Brown \& Stanley, 1972), would have been expected. In fact (see Table 3) the glutamic acid content of duodenal microbes was greater than that of rumen bacteria. It is possible that the sampling procedure used might have influenced the composition of rumen bacteria and of duodenal microbes. Rumen bacteria were isolated from a single fresh sample of fibre-free digesta withdrawn from the rumen $1 \mathrm{~h}$ after feeding whereas the duodenal microbial fraction was isolated from a sample of digesta which was representative of a $24 \mathrm{~h}$ collection of duodenal digesta which had been stored at $4^{\circ}$. Short-term chilling of rumen bacteria has been reported to increase the yield of bacteria prepared by differential centrifugation (Dehority \& Grubb, 1980), presumably by removing adherent bacteria from plant fibre (Merry \& McAllan, 1983). If this finding relates also to duodenal digesta then the sample of microbial material obtained may have contained bacteria normally adherent to fibre, which would not have been present in the rumen bacterial samples. In this context, Merry \& McAllan (1983) observed that bacteria associated with the rumen liquid phase contained greater amounts $(\mathrm{g} / \mathrm{kg}$ total $\mathrm{N})$ of diaminopimelic acid than did bacteria isolated from the rumen particulate phase.

\section{D-Amino acids as markers}

The quantities of microbial $\mathrm{N}$ entering the small intestines of the cattle given the four experimental diets were calculated using either the concentrations of D-alanine or D-glutamic acid in duodenal microbes or rumen bacteria and are given in Table 5. Although estimates 
for the amounts of microbial $\mathrm{N}$ entering the small intestine daily based on $\mathrm{D}$-amino acid contents of either duodenal microbes or rumen bacteria were closely correlated $(P<0.001)$ with estimates based on ${ }^{35} \mathrm{~S}$ as a marker, all estimates for microbial $\mathrm{N}$ based on D-amino acids were significantly greater than those obtained using ${ }^{35} \mathrm{~S}$ (duodenal microbes: D-alanine, $P<0.001$; D-glutamic acid, $P<0.001$; rumen bacteria: D-alanine, $P<0.05$; D-glutamic acid, $P<0.001$ ). Indeed, some individual estimates for the quantities of microbial $\mathrm{N}$ entering the small intestine based on D-amino acids as markers were in excess of the total quantities of non-ammonia- $\mathrm{N}$ entering the small intestine. Apart from the possibility that some D-alanine or D-glutamic acid of feed origin escaped fermentation within the rumen there were no apparent reasons for these differing estimates for microbial $\mathrm{N}$ entering the small intestine determined using D-alanine or D-glutamic acid as markers. When it is further considered that the contribution of protozoal $\mathrm{N}$ to microbial $\mathrm{N}$ would have been underestimated, then considerable uncertainty must be attached to the use of D-alanine or D-glutamic acid as markers for microbial protein entering the small intestine.

The authors wish to thank Messrs B. Brown, D. Smith and D. Robertson for care of the animals and the Agricultural and Food Research Council and the Deutsche Forschungemeinschaft for financial support.

\section{REFERENCES}

Agricultural Research Council (1980). The Nutrient Requirements of Ruminant Livestock. Slough: Commonwealth Agricultural Bureaux.

Agricultural Research Council (1984). The Nutrient Requirements of Ruminant Livestock, Suppl No. 1. Slough: Commonwealth Agricultural Bureaux.

Brown, C. M. \& Stanley, S. O. (1972). Journal of Applied Chemistry and Biotechnology 22, 363-372.

Buttery, P. J. (1982). In Forage Protein in Ruminant Animal Production, Occasional Publication, British Society of Animal Production, no. 6, pp. 1-12 [D. J. Thomson, D. E. Beever and R. G. Gunn, Editors]. Thames Ditton: British Society of Animal Production.

Coleman, G. S. (1975). In Digestion and Metabolism in the Rumen, pp. 149-164 [I. W. McDonald and A. C. I. Warner, editors]. Armidale: University of New England Publishing Unit.

Czerkawski, J. W. (1976). Journal of the Science of Food and Agriculture 27, 621-632.

Dehority, B. A. \& Grubb, J. A. (1980). Applied and Environmental Microbiology 39, 376-381.

Frank, H., Nicholson, G. J. \& Bayer, E. (1978). Journal of Chromatography 167, 187-196.

Garrett, J. E., Goodrich, R. D. \& Meiske, J. C. (1982). In Protein Requirements for Cattle: Symposium, pp. $23-25$ [F. N. Owens, editor]. Oklahoma: Oklahoma State University.

Greife, H. A., Rooke, J. A. \& Armstrong, D. G. (1983). Zeitschrift für Tierphysiologie, Tierernährung und Futtermittelkunde 50, 36-37.

Harrison, D. G., Beever, D. E. \& Osbourn, D. F. (1979). British Journal of Nutrition 41, 521-527.

Hutton, K., Bailey, F. J. \& Annison, E. F. (1970). British Journal of Nutrition 25, 165-173.

Kaiser, F. E., Gehrke, C. W., Zumwalt, R. W. \& Kuo, K. C. (1974). Journal of Chromatography 94, 113-133.

Leng, R. A. (1982). British Journal of Nutrition 48, 399-416.

Lindsay, D. B. \& Armstrong, D. G. (1982). In Forage Protein in Ruminant Animal Production, Occasional Publication, British Society of Animal Production, no. 6, pp. 13-24 [D. J. Thomson, D. E. Beever and R. G. Gunn, editors]. Thames Ditton: British Society of Animal Production.

McAllan, A. B. \& Smith, R. H. (1972). Proceedings of the Nutrition Society 31, 24A.

McMillan, L. (1982). D-Amino acids in the ruminant digestive tract. $\mathrm{PhD}$ Thesis, University of Newcastle upon Tyne.

Mathers, J. C. \& Miller, E. L. (1980). British Journal of Nutrition 43, 503-514.

Mathison, G. W. \& Milligan, L. P. (1971). British Journal of Nutrition 25, 351-366.

Merry, R. J. \& McAllan, A. B. (1983). British Journal of Nutrition 50, 701-709.

Ministry of Agriculture, Fisheries and Food (1975). Energy Allowances and Feeding Systems for Ruminants: Technical Bulletin no. 33. London: H.M. Stationery Office.

Rooke, J. A., Greife, H. A. \& Armstrong, D. G. (1984). Journal of Agricultural Science, Cambridge 102, 695-702.

Rooke, J. A., Greife, H. A. \& Armstrong, D. G. (1985). British Journal of Nutrition 53, 691-708.

Schliefer, K. G. \& Kandler, O. (1972). Bacteriological Reviews 36, 407-477.

Siddons, R. C., Beever, D. E. \& Nolan, J. V. (1982). British Journal of Nutrition 48, 377-390.

Storm, E. \& Ørskov, E. R. (1983). British Journal of Nutrition 50, 463-470.

Vogels, G. D., Honpe W. F. \& Stumm, C. K. (1980). Applied and Environmental Microbiology 40, 608-612.

Williams, A. G. \& Harfoot, C. G. (1976). Journal of General Microbiology 96, 125-136. 